\title{
The Causes of the Balkan Wars 1912-1913 and their Impact on the International Relations on the Eve of the First World War
}

\author{
Edit Bregu \\ PhD Candidate, Head of Political Science Department, \\ Political Science Faculty, "VItrina" University \\ e-mail:edit_kane@yahoo.com
}

\section{Doi:10.5901/mjss.2013.v4n9p115}

\begin{abstract}
The Balkan Wars of the 1912-1913 are the most important event in the history of the Balkan people and beyond. They are composed of a series sharp and bloody conflicts that swept Eastern Europe in the recent years. During the First Balkan War, the Ottoman Empire fought the united alliance of the Balkan states which included Bulgaria, Greece, Montenegro and Serbia. During the Second Balkan War, Bulgaria fought the coalition of Greece, Montenegro, Serbia, Romania and the Ottoman Empire. If we talk about the origins of the war, we must emphasize that the situation of the Balkan wars at the time and especially the situation that followed, was very alike to the conditions that existed before the Turks came to Europe. At that time, both during and after the Balkan Wars, the Christian states constantly fought against each other for hegemony in the peninsula. But in terms of international relations of the time it should be noted that since the end of XVIIIth century Paris, London, Vienna and St. Petersburg had a special operational plan for dealing with the problems in the East. For the more serious and real judgment we should also see the impact and performance of the situations and events in the Balkans, with the new changes in the geopolitics of the European continent, at least since the early nineteenth century and the credit for this goes to the European Concert (1815).
\end{abstract}

Keywords: Balkan wars, states, Ottoman Empire, Great Powers, annexation, national aspirations, territories, coalition ect.

\section{Introduction}

The Balkan Wars were a series of sharp and bloody conflicts that fell over South-Eastern Europe during the fall of 1912 and winter, spring and summer of 1913. If we'll talk about the origin of the war, we should emphasise that the situation, during and after the Balkan Wars, was reminiscent of the conditions that existed before the arival of the Otoman Empire in Europe. At that time, during and after the Balkan Wars, christian states were in constant conflict against each other for hegemony over the peninsula. However, during the otoman occupation, even if the people were troubled and beaten, national consciousness didn't vanish entirely. Simultaneously, we are aware over the advancement of national spirit in Balkan, starting from the beginning of the turkish occupation. Various authors assert that, the Great Powers had anticipated the division of the Otoman Empire almost a century before the Great Easter Crisis.

\section{European Concert, securing peace stability and the removal of nationalism}

Austrian Metternich, Fon Hardenberg of Prussia, Castlereagh of Brittain, Tsar Alexander the 1st of Russia, Taleyran as representative of Louis XVIII, just restored in France, were the players of this concert. These five men attained what they had planned. After the Vienna Concert of 1815, "Old" Europe, characterized from ongoing wars for power, experienced the longest pediod of peace it ever had. In 40 years there were no war between the Great Powers. After the war at Crime in 1854, there was no general war for another 60 years. This was due to a strong equilibrium, wich proposed the existence of France, Germany, Austro-Hungary and Russia as main elements, having the support of England wich had the naval fleet superiority. In this complex structure based not only Europe, but also ensuring U.S. Kissinger says that:" A peaceful international order punitive withholding because winners were loads of war-weary task to keep track of a country that is determined to derail the chosen path".1 That would be the worst of the Treaty of Versailles. Winners of the Congress of Vienna as the winners of World War II avoided this kind of mistake. It was not easy to tregoheshe patient and generous to France, which was trying to subdue and rule Europe. But statesmen in Vienna, concluded that Europe

${ }^{1}$ Borici Gj. (2008), Politika, marëdhëniet ndërkombëtare dhe diplomacia në shekujt e historisë 1600-1899, Tiranë : Geer Editor , pp. 275 
would be safer if France will be relatively pleased than offended and unfriendly. France was stripped of her conquests, but what you gave her borders "ancient" pararevolucionit therefore, although they represented a much wider territory he had run out of Richelieu. So if you see a chronological unexplained events begin before East crisis, the Balkan Wars and after the First World War, we see that the world had been for nearly half a century of peace. The concert of Europe have experienced diplomats. Each of them have distinctive skills and knew how to use them properly. Undoubtedly pointed out: the aristocratic elegance and Metternich diplomatic, intelligence and cunning Taleyran, reasoning of Lord Castlereagh. And the results were seen with what is offered diplomacy, political and human history of those years. But immediately after this period resume military and economic forces have changed significantly. On the one hand, the scene of powers and interests, unfolding a multinational Ottoman empire too weak economically and militarily, whose ship was sinking path to take. Consequently, increased efforts of the Great Powers, especially Russia to take part when it happened (the Russo-Turkish War). On the other hand brings the creation in 1871 of the German state, the great Chancellor Otto von Bismarck. Germany have an economic and military too large, changing the ratio of forces on the continent. But that failed merger Chancellor of Germany would not live forever, and his descendants will be sadly lacking in diplomacy what he had majority, maturity. Various analysts have concluded that, Congress of Vienna, among other things, in favor of peace, nationalism aside. Nationalism was seen by European leaders as the cause of revolutions which undermine the existence of traditional monarchies. "The term revolution as a notion and doctrine had no greater enemy than the Prime Minister of Europe, Prince Klemence von Metternich ... According Metternich and the threat of an outbreak of a revolution, nationalist movements to come from the conquered peoples".2 So, in a way closely related revolutions nationalism, were challenge decisions of the Congress of Vienna. But time will show that despite efforts to ban Metternich revolutionary movements, they will not stop, even Metternich itself will leave the political scene. So after the concert, Germany and Italy were left as divided states, but strong nationalist movements and revolutions led to the unification of Italy in 1861 and Germany in 1871.

\section{Post-Bismarc policy position}

Powers became aware of Prussia's military potential, with its victory over Austria at the Battle of Königgrätz 1866's. Meanwhile, four years later, they saw the Prussian army to destroy fortifications Parisian. Those who had been a symbol of power and majesty. On the other hand, it was made clear throughout that greatness, French culture and British absolute dominance in trade and industry was coming to an end is. Another superpower would come on stage, disrupting European balance, and giving a new breath and European policy interests. Parallel with this change, walked and ran and one of the leading figures in the history of German Chancellor Otto Eduard Leopold von Bismarck-Sainthausen. Bismarck was one of the most prominent European aristocrats of the nineteenth century. Bismarck was born on 1 April 1815 and died on 30 July 1898. Year of birth of Bismarck ëahtë year marked the political and diplomatic agenda of the European continent. That year, the coalition holy accounts closed once and decided to Napoleon Bonaparte and an international order in the world. It was this international order, which Bismarck inspired to achieve what will be making his name immortalized in centuries of history: "Unification of all German states into a single state". ${ }^{3}$ Realpolitik Bismarkiane (foreign policy based on the calculation of the force and the national interest), brought the unification of Germany in 1871, right in the heart of France, who had driven the hated union and, in the palace of the statements in Versailles. But reunification Realpolitics made to close itself, reaching the opposite of what he expected to arrive. On the other hand Realpolitics made the mistake of starting life insulting state of permanent enemy who will not forget tja tja reward until just a few years later with the same currency even more, thus insulting the pride of the German nation seriously. Since the modern state system emerged at the time of Richelieu, countries on the periphery of Europe: Britain, France and Russia, continue to put pressure on the center. Now, for the first, middle, becoming very strong pressure to the periphery. He still called the Concert of Europe, was actually divided into two groups hostility, enmity between France and Germany and the growing animosity between the Austro-Hungarian and Russian. This hostility between Russia and Austria, managed to overcome the monarchs unitetitn conservative. Pan-Slavism and expansion fanatic and outdated adventurous came to the aid of Russian policy in the Balkans. Just cause fear stays parallel to the Austro-Hungarian empire. Over time, the conflict in the Balkans, Russia and Austria became unmanageable. If the balance of power had functioned in the form of its most pure, the Balkans will be divided into spheres of influence of Russia and Austria. Bismarck at the Congress of Berlin was arrogant, but because. He had the ability to understand the incentives of participants went on to meet the disagreements, and had as its ability to give the characters realize that others working in the interest of tëtjerëve, he had no personal

\footnotetext{
${ }^{2}$ Borici Gj. (2008), Politika, marëdhëniet ndërkombëtare dhe diplomacia në shekujt e historisë 1600-1899, Tiranë : Geer Editor , pp. 295 ${ }^{3}$ Kissinger Henry, (1999) "Diplomacia", Tiranë: Laert Editor, pp. 136
} 
interest and that of the best of . In other words, he cleverly hinted that there was no "client" of the Balkan peoples, despite his main goal in diplomacy, was to establish such a balance to prevent alliances antigjermane. But, regardless of merit, if any leader and divine what they had given to his country, is not eternal, is first and foremost a man, a mortal. Time Bismarck was golden but if he had the ability to distinguish the finish line where military strength and diplomatic used it, those who came after him had these skills, and it will prove fatal not only to the German nation but for all mankind. "Nobody eats from the tree of immortality impunity", Bismarck wrote for his friend von Roon 4 . In this sense Bismarck planted the seed, not only the achievements of his country but his tragedies of the 20th century. After unification, Germany became the most powerful country on the continent and consistently strengthened after each decade. Berlin turned into a European economic center becoming a symbol of that development. But besides the economic and military, diplomacy postbismarkiane left much to be desired. Content virtue that had so rationally and appropriately Bismarck, his successors had little to say not at all. 15 years after the death of Bismarck, these positions will bring their fruits in conflicts that would affect the Balkan Peninsula, and throughout Europe and the world in one of the major wars that involved humanity.

\section{Macedonia}

It is known that 100 years before the Balkan wars, the entire Balkan Peninsula, the Aegean Sea and Turkish straits to the border of the Russian Empire, Austria-Hungary, with few exceptions, was under Turkish sundmin. As a result of developments known during the nineteenth century, the Turks were retreating southward detyuar of birth and now the remaining parts of the southern peninsula. "However, states created in the liberated areas in the nineteenth century and twentieth century fillimtë as Greece, Serbia, Romania, Montenegro, Bulgaria, entirely governed by monarchies, where borders were almost ambiguous and lacked stability Peninsula international". ${ }^{5}$ Austria and Russia pursue their interests in the Balkans. Geography and Ethnography, the report said Cornegier Foundation, have divided the Balkans into two spheres of influence, eastern and western, Bulgarian and Serbian areas. History of diplomatic or insert them under Russian or the Austrian influence. Thus there are two opposing withdrawal: Withdrawal "German" from north to south and pull "Slavic" from east to west. "Vardar Valley, which divides Macedonia into two parts, was destined to be the arena where the two influences meet and encounter". ${ }^{\prime}$ Russia has outlined the boundary of the area of influence since the Treaty of San Stefano, which all form part of Macedonia's inherent Bulgaria. Austrian politics has counter-attraction to the formation of the Russian secret treaties of 1881 and 1889 by Serbian King Milan Obrenovic, who was promised areas of Vardar Macedonia and the western half, in order for Serbia to give up goals Adriatic, to give consent to sanjak of Bosnia and Herzegovina annexed all countries serbishtfolëse to Zagreb. Any increase of the Serbian Kingdom, any extension to the sea, especially the Adriatic, each elevation and reinforcement of national consciousness of its people, endanger the Dual Monarchy. Within the Austro-Hungarian Empire are millions of Slavs and "Austrohungaria can not arinin in their appearance in the sea - Trieste and Fiumme - without going through the territories inhabited by Slavs of the south". While pan-Slavism threatened the integrity of Austria-Hungary, the main features of this latest in the Balkans was a harsh suppression of national aspirations among its populations of the South Slavs (Kroaciosë residents, Dalmatia and BosniaHerzegovina), a wary and jealous opposition to any territorial or resource achievement of the Kingdom of Serbia and a strong determination to stop the constant Serbian expansion to the Adriatic. For these and other reasons, that many scholars, among whom and J. Schurman, claim that the cause of the war between Turkey and the Balkan shtetve 1912 was Macedonia. Being geographically between Greece and Serbia, Bulgaria, Macedonia and as a race-types ethnic mix was intended to act as a magnet to newly freed Christian nations of the Balkans. Macedonia was and is at the crossroads of the Balkan Peninsula. To go from Central Europe to the Aegean port of Thessaloniki, or the Adriatic Sea in Istanbul, traders will always pass through Macedonia, to avoid mountain roads. Furthermore, and Bismarck, known for his contempt for all Balkan affairs, acknowledged its strategic position. "Those who own the Vardar River valley, he said, are the masters of the Balkans". ${ }^{8}$ So all these facts lead us to think that Macedonia has been one of the causes of the Balkan conflicts even just getting started and the existence of this region, and being in that position and what specific geographic mix populations, such that for all these country would be subject to often targeted by neighbors for political or economic purposes and military. Gives a very interesting definition and Edit DURHAM, which "concerns the Balkan"

\footnotetext{
${ }^{4}$ Luftërat e tjera ballkanike, (1993) Tiranë : Onufri Editor, pp. 5-6

${ }^{5}$ Luftërat e tjera ballkanike, (1993) Tiranë : Onufri Editor, pp. 36

${ }^{6}$ Schurman J, (2006), Luftërat ballkanike, Tiranë : Onufri Editor, pp. 21.

${ }^{7}$ A. Michell Rodin, "IMRO and the Macedonian Question", Skopje,f. 19. Cituar nga M.Gleny, vepër e cituar, f. 156.

${ }^{8}$ Durham E, Brenga e Ballkanasve, Tiranë: Argeta-LMG Editor, pp.73
} 
says: "Macedonia, if observed, is a very elastic term, which is summed up for all those countries which wish to ask the annex. It is a free term, and therefore the wrong term. I have met with people who believe that there is a breed called "Macedonian" ... The truth is that in this country that has no boundaries and that its own officials had no limits never stable, six races live peoples who all have claims to the right to view". ${ }^{9}$ This statement is quite original because it shows us that some people are fragile and mixed culture or ethnicity, which often become the object of fulfilling the interests of stronger nations or ethnicities that rrthojnë more solid. In other words, they have a national identity not steady because of various wars, they spend time or become part of a state, and another time, becoming so in this sense a permanent source of conflict. In case you have chosen to study the existence and consequences of these differences Macedonian, they will be "the match will light cools the conflict" and wars that will not only feel the Macedonians, but all the peoples of the Balkans.

\section{The Tractat of Saint Stephan and the Berlin Congres}

The concept of nationalism, which found from France and the German states in the early nineteenth century began to shpërhapej in the Balkans. The initial impact was mainly cultural. Intellectuals made great efforts to standardize and all my popular daily Balkans also often reminding states that had existed in the Balkans before Ottoman invasion. Very soon became the focus of political nationalism, a desire to achieve national unity motivated Balkan countries to deal with their former occupiers ottoman. Balkan leaders assume that only the achievement of national unity after their states can go towards the development and prosperitetit.In this aspect of the Balkan peoples tried to follow the example of the political and economic success in Western Europe, especially West Germany by adopting the concept of nationalism as a model for their national development. Balkan peoples perceived nationalism as a justification for the creation of special geopolitical units. Vasil Levski, a Bulgarian revolutionary activist of the nineteenth century, says: "We are a people who want to live in complete freedom in our land, where Bulgarians live in Bulgaria, Thrace and Macedonia." This concept of Western European nationalism moved the old Ottoman 'millet' in the Balkans, which actually had allowed every major religious group autonomy in administration management. The millet system allowed the Muslims, Orthodox, Catholics and Jews live together without inserting the nose into the affairs of one another. This system gave the Balkan peoples a limited degree of cultural autonomy. Every Balkan people imagine restoring medieval empires that used to base their national ideas. Bulgarians asked borders of the empire of the first or second Bulgarian revival of Byzantine Greeks, Serbs and Montenegrins and asked to lie on the territory of the empire of Stephen Dushan. In 1876 Serbia and Montenegro war against the Ottoman Empire to create large national states in the western Balkan Peninsula. In the same year an anti-Ottoman revolt erupted in Bulgaria. In 1877 Russia intervened in the Balkans, Bulgarian nationalists allied. After nine months of hard fighting, the Russians dominated. The Treaty of San Stefano, signed in March 1878, and ended the Russo-Turkish war by creating an independent state of Bulgaria's large and expanding Serbia and Montenegro. The Treaty of San Stefano maximum territorial aspirations fulfilled Bulgarian nationalists. Bulgaria's new included most of the territory in the eastern Balkan peninsula between the Danube and the Aegean Sea. It also included Macedonia. For the first and only time in modern history, a Balkan nation had achieved all its national goals. The Treaty of San Stefano was faced with a negative response from core Europe, which for the last 200 years had the privilege of international arbitration matters. A desire to limit the ambitions of the Russian Empire in the Balkans and to restore order in chaotic conditions Ottoman Europe, especially by Austria-Hungary and Great Britain made the major powers to accept the offer of Otto von Bismarck to organize a conference to resolve the Balkans. Bismarck promised to serve as an "honest broker, who really wanted to do business." Bismarck invited the representatives of the Great Powers to meet in the German capital. After the Congress of Berlin was attended by leading diplomats of the time, including Lord Salisbury Great Britain and Count Andrassy of Austria-Hungary. This significantly reduced the size and independence of the new Bulgarian state. Instead of a large independent Bulgaria, the Berlin Congress created an autonomous Bulgarian principality under the Ottoman sovereignty, a semi-autonomous Eastern Rumelia under the authority of the Ottoman Sultan, and the back Macedonia in direct rule of the sultan. These decisions were catastrophic for Bulgarian nationalism. E.Geshov Ivan, who led Bulgaria in the First Balkan War in 1912, wrote: "When we read in Plovdiv ominous Times in July 1878, the published text of the agreement, in which diplomacy ditëshkurtër Berlin our shared homeland, remained fascinated. Was such a possible injustice? Could one of them was turing into injustice ". Berlin Congress also recognized the independence of Serbia too full a bit smaller and Montenegro deprived of gains versus sanctioned in San Stefano Herzegovina Sanjak of Novi Pazar and northern Albania. Austria-Hungary advanced to the Western Balkans and

${ }^{9}$ Schevill Ferdinand, (2002)“Ballkani, historia dhe qytetërimi", Tiranë: Wegen Editor, pp.371 
occupied Bosnia-Herzegovina and Novi Pazar sanjak. These territories were de jure part of the Ottoman Empire. They were also the national aspirations of Serbia and Montenegro. Greek continuing claims led to a tussle in Berlin decisions. Bulgarians were not the only ones who felt frustrated over the Berlin decisions. Greeks, Montenegrins and Serbs are perceived as the Treaty of Berlin as an obstacle to their national aspirations. The famous French historian and A.Rambo E.Lavis stated: "Rarely in history faced the situation so strange and so unfair. Equilibrium in the Balkans broke". Now, in fact, seemed to Austria near the Mediterranean Sea and Carigradit (Kostandnopoja) than Russia. Serbian people, hoping to rebuild the national integrity, against his will and explicit, found himself in July 1876 divided in three parts, while Austria tried at all costs to establish any kind of relationship with. Similarly, against the wishes of his people, and Bulgaria was divided into three parts.

\section{Bosnian crisis of $1908-1909$}

The decisions of the Berlin Congress made the Balkan peoples to oppose the Ottoman Empire and Austria-Hungary, and, moreover, Balkan nations opposed each other. In this complex situation was strengthened people's liberation movement rather than Turkish (where, among other things, attracted the attention of the powerful movement of Albanians, especially with known activity during the League of Prizren and beyond), who had remained under the yoke of the Sultan and movement of the South Slavs and other ethnic groups who were under the power of Austria-Hungary. Serbia dominated by llia Garashanini program (Narçertanje 1844), provided a territorial expansion of Serbia, who became leader of the activities in the field of foreign policy of the country. This document is known as the "bible of Serbian nationalism". He pointed to the fact that the Serbian expansion will not only mean the destruction of the Ottoman Empire (European part), but with a potential conflict against Austria, which was preparing her go back brakes Turkish possessions in the Balkans. Under this program was alive Serbia should the former glory of the kingdom of Stefan Dusan. But the limits of this new empire, "Naçertanije" - will enter many areas of neighboring countries including Northern Albania and Kosovo, the Serbian minister baptized with the name "Old Serbia". This view was reinforced by the fact of annexation of Bosnia and Herzegovina by Austria-Hungary in 1908 and its goal for itself to ensure access to the Aegean Sea, the region of Thessaloniki. Austrian monarchy was because at that moment and the situation was in favor of it, not to mention leaving Germany and support. Austria reached as far as stating that: "I do not know the power of the sultan in this country and that will detach from the empire, then fire you really threw gasoline". ${ }^{10}$ Austria, even strengthened its position in the Balkans without giving any compensation Russia, the latter in military terms, in that moment too incompetent to withstand an Austria which was backed by Germany. In addition, Russia does not enjoy the support of France and Britain that their attitudes had clearly indicated that it will not engage in a war in Serbia's interest. These attitudes led to the end of March 1908, Russia to recognize the annexation of Bosnia and Herzegovina. In fact, this annexation, instead of serving for a solution to the issue or sedation of the South Slavic population, led to a further aggravation of the situation. The first simple this crisis was resolved through diplomacy and not through war. In January 1909, Aehrentali strengthened Austria's diplomatic position through an agreement with Turkey, which the Ottoman government recognized the annexation of Bosnia and Herzegovina by Austria in exchange for monetary compensation. On the other hand that was developed in 1906 with Serbia "War pigs" and trade blockade. Serbia could not be supported by Russia which was militarily too weak to face a war at that moment, while Britain's Liberal government was preoccupied with social legislation and in France Klemansoit government was completely anti-German, this Last behind Austria despite reservations. But despite the success of diplomatic and peaceful solution by Austria and Germany, on the international reputation and they also suffered losses in the sphere of interests because they abandoned the strategic sanjak of Novi Pazar. It should be noted and something that is very sensitive and in the interest of our study, that the Austrian monarchy, this solution was a "mixed blessing". On the one hand, Austria achieved its purpose, which was the annexation of the province, and the fact of the forced carry-on as Serbia or Russia-in the "surrender" in the face of this reality. But the other side of the coin was that would be very difficult for Austria to administer or govern these provinces, because the very southern Slavs were against the annexation. Russia will use this fact as to "take revenge", prompting a Balkan peoples resistance against the Habsburg Monarchy. While all these reasons, Serbia asked before whether you can it withstand Austria - Hungary. This threat became one of the main reasons that forced the Serbian ruling circles of felt for a territorial expansion towards the Turkish possessions in Europe, primarily in Macedonia and other regions in Albania etc..

${ }^{10}$ Durham Edit, (2000) "Brenga e Ballkanasve", Tiranë: Argeta-LMG Editor, pp. 71 


\section{The Tripolitania War}

While the Moroccan crisis has attracted the attention of the Great Powers, Italians realized that they had made an agreement with France in December 1900, an agreement was proper. In exchange for a free hand to the left France in Morocco, Italians now aiming to achieve a victory similar to that of the French in connection with the North African provinces and Kirenajkës Tripolitannia, which were still part of the Ottoman Empire. Italy had faith and in fact it turned out to former true that Austria and Germany would not mind to avoid disturbing the tripartite alliance. In October 1909, Italy further strengthened its diplomatic position, by ensuring Russia's consent to receiving Tripolitannia from Italy, in exchange for Italy's support for Russia wanted changes in the Straits Convention. On 28 September 1911, the Italians suddenly handed an ultimatum to Constantinople, where required the Ottoman government, within twenty-four hours, to agree to an immediate invasion of Italy by Tripolitannia, this requirement is justified on the grounds of establishing " law and order ". Twenty-four hours later, no matter the response of the Turks, Italy declares war on Turkey. On November 5 , they announced the annexation of these territories, which is called Libya, the ancient Greek name for this region of Roman North Africa. After about a year on October 18, 1912, in an agreement signed in Lausanne, Switzerland, Turks made peace with Italy and agreed to withdraw troops from Tripolitania and Kirenajka. This decision not only you imposed on them by the Italian successes on the battlefield, but also of a new attack on the Ottoman Empire was being prepared, this time of the Balkan countries. In fact, the great powers such as France and Britain were not too concerned about the fate of this population or those tojeve which were almost deserted, than the fact that any attack on the Ottoman Empire was a precedent for the launch of the Eastern Crisis. But Germany and Austria feared that the Italian attack would serve as an incentive to attack Russian or Balkan countries over turkey. Time showed what great powers feared happened. Despite contradictions Balkan joined forces to create an alliance against Turkey. In the landscape of international diplomacy Tripolitannia War, regarded as a driver of the Balkan peoples in the struggle for independence from Turkey. All Balkan countries, except Romania were on the border with the Ottoman Empire and all were keen to take land from its holdings. Russians for a long time had sought to form a coalition of Balkan countries, but until then it had not been possible because of rivalries and extreme positions itself as the Balkan and their fear that Russian aid will not be turned the reason to come under another pick, but not this time Russian Orthodox Muslim. So at any time there was a fear of becoming hostage to Russia. Italian attack on Tripolitania succeeded him what he could not achieve for a long time Russian diplomacy. While an important part of the Turkish army was in North Africa, the Balkan countries saw an opportunity or a situation conducive to realize their ambitions against the Ottoman Empire. So after the engagement of Turkish troops in Africa and the impact of Russian diplomats and agents, Balkan countries except Romania gathered in a coalition and saw for the first time admitted the possibility of the recovery table to pluricentennial Ottoman yoke.

\section{Albanian insurrection in the years $1910-1912$}

These uprisings served as a powerful catalyst in the development of events in the Balkan peninsula, at the end of the first decade of this century. Researcher very dear to Edith Durham Albanians had thought that if it was to give a definitive and Albania (after the Treaty of Berlin), definitely you will not need to be made other moves popullsish. The view that existed after this Treaty, to recognize Albania as its only fair mountainous strip of land along the coast, will bring great disaster. "A nation like this, with all the special quality, swinging should have enough places to live. If you will not be given, they will receive them himself. This is one of the most fundamental issues of current difficulties. While Albania remains without its borders, under the so-called Turkish government, its status will be anarchic and Balkan situation has improved to be almost impossible. ${ }^{11}$ Taking into account the situation of that time would be absurd to accept that the Albanian factor has not affected the throes of the Ottoman Empire. In this direction, attentive and serious researchers and undisputed facts convince us that one of the main reasons, if not the main one, the outbreak of the Balkan wars are Albanian uprisings, especially the General Uprising of 1912's, the thing which forced the Ottoman Empire on August 17, 1912 to accept demands for autonomy Albanian insurgents in four Vilayet the area $90100 \mathrm{sq} \mathrm{km}$ and a population of 2,725,410 inhabitants. Certainly the Ottoman Empire was found in front of a fait accompli, Albanian patriots in November 1912 had raised the Albanian flag in some cities to crowned in Vlora on 28 November 1912. The right choice of the Albanian question, did not like anyone Albanian territories around the country and their actions created a folder that terrible conflict made many disasters and tragedies with colossal damage for nearly a century. Concerns of the Balkan states, especially Serbia, increased more after the liberation of a number of major cities of Kosovo Vilayet etc. and,

${ }^{11}$ Shala Xheladin, (2006), «Cështja shqiptare dhe diplomacia serbe 1912-1913 »,Prishtina, pp.12-13 
moreover, after the triumphal entry kryengitësve more than 30,000 Albanians in Skopje, the capital of Kosovo Vilayet, this success was a blow to conspiracy spring Balkan alliance. "Tension increased after the count's proposal Berhtold Austro foreign minister, on August 13 Great Powers, the best course of action for decentralization measures the Sublime Porte in the Balkans of 169,000 sq km, respectively vilajets six, and four of whom vilajets Albanian ethnic Albania would form the 90100 square kilometers». ${ }^{12}$ Historian Ferdinand Schevill writes that victory felt Albanian allies, already inevitable, through which Albania was being built as an autonomous state consisting of four vilayet, Shkodra, Janina, Monastir and Kosovo. In fact, the reality was that, if fighting the Albanian proposal will be accepted each of the four allies would see the door closed in a given province, which each particularly coveted. But after uprisings concerned Albanians, was the Russian pan-Slavism, which in order to achieve its goals, hiding behind the Serbian factor, continually urging him to targeted Albanian factor. In view of these personal interests Russian diplomatic activity conducted a succinct trying to secure the support of England and France in favor of its Balkan allies. "First in the Balkans are our interests, the interests of Serbia, Montenegro, and Greece", would declare chairman of the Russian Government. So Albanian ideas of liberation and unification combined with claims of ruling circles in Serbia, Greece and Romania to foreign lands, where there lived measures popullisie contacts with the countries concerned nationality. Different scholars in their studies ee affect the issue of targeting Balkan countries for hegemony. This time paying special attention to the professor Damjanov Simeon, one of which was initiated in the developping events in the Balkans in 1912-1913." To establish their hegemony in the peninsula - he wrote - and then fought Bulgaria, Serbia, Greece and Romania. But, if Bulgaria was intended for hegemony through a natural attempt to unify national, relying on the fact that the Bulgarian population in the Balkans is more numerous in number, the hegemony of Serbia, Greece and Romania became possible only with the emergence of these countries outside the framework of legitimate expectations only way the invasion of foreign lands (mainly Albanian and Bulgarian lands) ${ }^{13}$. This fundamental distinction must always keep in mind in assessing the political and territorial claims of each of the countries in the Balkan war.

\section{Socio-economic situation of the Balkan peoples under Turkish rule}

The Balkan region and especially those who seceded from the latest Turkish Empire, Ottoman rule inherited from a very low economic level. Most of the population lived in the countryside, the market economy was in a phase of stagnation, lack infrastructure, not to forget that the bulk of the population was illiterate. Here's how Demeter Anatakoviq Austrian consul expressed in Sarajevo in the period of Ottoman occupation, which he inter alia kostatonte policy reforms that advertisements had entered a vicious circle. "Sarajevo is dead. Trade and crafts are stopped altogether. Last weekend the city was brought very little food shopping goods. Eye not beasts of voice, or because they are from military requisitioning, or because the peasantry has mountains to save them ... As seizures have often allowed themselves to emphasize the villagers, Muslims and Christians alike, are burdened in every way ...". ${ }^{14}$ Many studies refer to the fact that the political character of the reasons that conditioned the beginning of the Balkan War, should be included and the socio - economic and population conquered by the Turks, which was kept under a pressure of wild and was deprived of political rights, national, social, religious and other rights. "And, besides political and socio-economic slavery was strengthened and national oppression .... While the ruling circles of the Turkish state refused to reforms proposed course of action in the Congress of Berlin. After Bulgaria's declaration of independence in 1908, this population experienced an even more ferocious repression. Most progressive representatives enslaved population under the European dominions of the Ottoman Empire and the Balkan states community, trying to find a radical solution to the national issue, which was actually a continuation of the liberation war renaissance period for the elimination of feudal and semi system national self-determination for the people not Turkish. Given the rapidly developing events and conditions on which was popullli,

12 Glenny Misha,(2007) "Histori e Ballkanit 1804-1999", Tiranë: Toena Editor, pp. 122

${ }^{13}$ Glenny Misha,(2007) "Histori e Ballkanit 1804-1999", Tiranë: Toena Editor, pp. 81

${ }^{14}$ Reconstruction (1865-1877) in U.S. history, period during and after the American Civil War in which attempts were made to solve the political, social, and economic problems arising from the readmission to the Union of the 11 Confederate states that had seceded at or before the outbreak of war. Each state had to accept the Fourteenth or the Fifteenth Amendment intended to ensure civil rights of the freedmen. The newly created state governments were Republican in character and were governed by political coalitions of blacks, Northerners and Southerners who collaborated with the blacks and Northerners. Sotherners particularly resented the activities of the Freedmen's Bureau, which Congress had established to feed, protect, and help educate the newly emancipated blacks. The use of fraud, violence and intimidation helped Southern conservatives regain control of their stete governments, and, by the time the the last Federal troops had been withdrawn in 1877, the Democratic party was back in power. The most fundamental failure of Reconstruction was in not effecting a distribution of land in the South that would have offered an economic base to support the newly won political rights of black citizens. (Du Bois, 1992) 
leading circles of the Balkan countries decided that they had been charged with the mission of resolving historical issues in their countries. The goals of the First Balkan War itself crash involving semi feudal system under the European dominions of the Ottoman Empire, where the Turkish population not subjected to savage repression of political, economic, national, social and religious. Another aspect was the struggle for the liberation of the enslaved fellow thing that would lead to national unity Balkan peoples and the establishment of homogeneous states. This aspect of homogeneity will make the confusion, the territory of the State the nationality. On behalf of the nation state will become mass expulsions, rape, murder and genocide, which unfortunately will accompany the Balkan region to this day. These goals, set in a certain way progressive character of the First Balkan War, continuing the idea of liberation Russo-Turkish wars of the nineteenth century, which makes that a good part of the Balkan peoples to gain freedom. She played the role of a bourgeois democratic revolution in European dominions of the Ottoman Empire. But the downside was that followed the war and other purposes can be realized. This caused controversy in defining its character. One of these contradictions was the annexation of Albanian and Macedonian territories. 